Int. J. Dev. Biol. 61: 81-88 (2017)

doi: $10.1387 / \mathrm{ijdb} .160006 \mathrm{sb}$

\title{
Valproic acid assisted reprogramming of fibroblasts for generation of pluripotent stem cells in buffalo (Bubalus bubalis)
}

\author{
PUSPENDRA S. MAHAPATRA, RENU SINGH, KULDEEP KUMAR, NIHAR R. SAHOO, \\ PRANJALI AGARWAL, BHABESH MILI, KINSUK DAS, MIHIR SARKAR, SUBRAT K. BHANJA, \\ BIKASH C. DAS, SUJOY K. DHARA and SADHAN BAG* \\ Division of Physiology \& Climatology. Indian Veterinary Research Institute, Bareilly, India.
}

\begin{abstract}
Generation of pluripotent stem cells by reprogramming somatic cells of quality animals has numerous potential applications in agricultural and biomedical sciences. Unfortunately, till now, reprogramming of buffalo fetal fibroblast cells (bFFs) has been very ineffient despite intensive efforts. Here, we attempted to enhance reprogramming efficiency by using the HDAC inhibitor valproic acid (VPA) in bFFs transfected with pLentG-KOSM pseudo virus carrying mouse specific pluripotent genes. FACS analysis revealed thatVPA treatment significantly increased $(p<0.05)$ GFP+ cells in comparison to VPA untreated control. Further, among different concentrations, 1.5 mM VPA was found to be optimal, increasing about 5 fold GFP+ cells and 2.5 -fold GFP+ colonies with significantly $(P<0.05)$ larger size as compared to control. These colonies were further propagated and characterised. The colonies displayed embryonic stem cell (ESC)-like morphology, normal karyotype, and were positive for alkaline phosphatase staining as well as immune-positive for the ESC specific markers Oct4, Nanog, SSEA1,TRA-1-60 and TRA-1-81. The primary colonies revealed significantly higher $(P<0.05)$ expression of pluripotent genes than control, which declined gradually on subsequent passages. The reprogrammed cells readily formed embryoid bodies in vitro and cells of all three germ layers. These results indicated that VPA treatment of viral transducted cells can improve the generation of induced pluripotent stem cells and help their long term maintenance in buffalo.
\end{abstract}

KEY WORDS: valproic acid, buffalo fetal fibroblast, reprogramming, mouse defined factor

\section{Introduction}

Embryonic stem cells (ESC) have wide applications in regenerative medicine as well as reproduction due to their property of pluripotency. However, advantages of ESCs cannot be fully exploited because of difficulty in their derivation, ethical consideration, genetic and epigenetic modifications during culture. Therefore, the current focus of research is on reprogramming of somatic cells into ESC like cells and their further differentiation into specific cell types. Progress in understanding of the transcriptional network, signalling pathways and molecules responsible for the maintenance of pluripotency in ESC, has paved the ways for generation of induced pluripotent stem cells (iPSCs) through nuclear reprogramming of somatic cells (Takahashi and Yamanaka, 2006). Similar genetic manipulation was used to generate pluripotent stem cells in human (Yu et al., 2007) and different domestic species such as pig (Ezashi et al., 2009), dog (Shimada et al., 2010), rabbit (Honda et al., 2010), sheep (Bao et al., 2011), goat (Ren et al., 2011), horse (Nagy et al., 2011), cattle (Han et al., 2011) and buffalo (Deng et al., 2012, Bag et al., 2012). iPSCs thus generated were found highly similar to ESCs in various aspects such as morphology, proliferation, gene expression, and in vitro differentiation.

Research conducted so far indicate that derivation of pluripotent ESCs in domestic water buffalo either from early stage embryos or from blastocyst are limited and the success rate has been very low (Sharma et al., 2011). Therefore, iPSCs technology can be used for deriving pluripotent stem cells in this species. Recently, attempt has been made to derive iPSCs in buffalo using proteins of buffalo defined transcription factors, however, the reprogramming efficiency was quite low and the reprogrammed cells could not be

Abbreviations used in this paper: AP, alkaline phosphatase; bFF, buffalo fetal fibroblast; ESC, embryonic stem cell; FACS, fluorescence-activated cell sorting; iPSC, induced pluripotent stem cell; VPA, valproic acid.

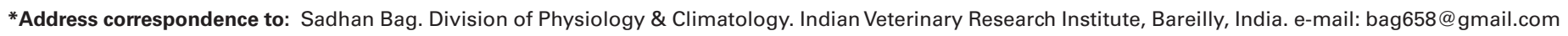



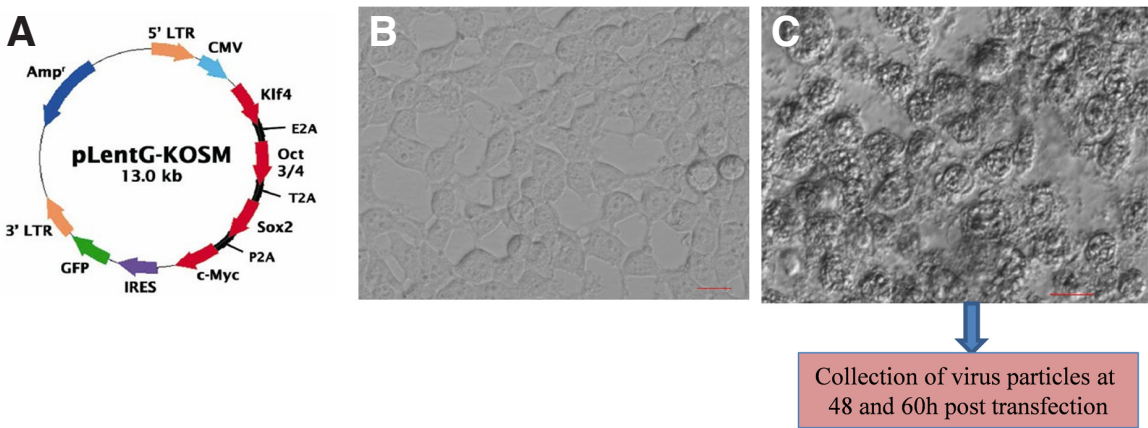

Fig. 1. Generation of virus particle. (A) A pLentGKOSM plasmid vector carrying mouse transcription factors. (B) A 293T cell before transfection. (C) A 293T cell $96 \mathrm{~h}$ after post transfection. propagated beyond $10^{\text {th }}$ passage (Deng et al., 2012).

Recently, a number of small molecules like histone deacetylase (HDAC) inhibitors valproic acid (VPA), a drug which is widely used for the treatment of epilepsy, mood disorders, and to prevent migraine headaches etc., suberoylanilide hydroxamic acid (SAHA) and trichostatin A (TSA) (Huangfu et al., 2008a), p53 siRNA (Hong et al., 2009), vitamin C (Esteban et al., 2010) etc have been reported to promote iPSC generation from mouse and human fibroblasts. A 100 fold increase in reprogramming efficiency has been reported in human and mouse fibroblast by using VPA (Huangfu et al., $2008 \mathrm{a}, \mathrm{b})$. Therefore, the present study was aimed to improve the reprogramming efficiency by VPA treatment of buffalo fetal fibroblast cells transfected with lentivirus carrying mouse derived transcription factors.

\section{Results}

\section{Valproic acid (VPA) tolerance of buffalo fetal fibroblasts}

The change of morphology of VPA treated bFFs has been presented in Fig. 3A. We observed that VPA treatment reduced the proliferation rate of bFFs significantly in comparison to VPA untreated fibroblast cells. However, within different concentration of VPA treatment, the proliferation rate was comparatively higher when the bFFs were treated with lower than $2.5 \mathrm{mM}$ VPA (Fig. 3B). While a large population of bFFs was not viable at 5.0 and $7.5 \mathrm{mM}$ VPA, a complete mortality was observed at 10.0, 12.5 and 15.0 mM VPA concentration (Fig. 3 A,B).

\section{FACS analysis for GFP+ cells}

FACS analysis on day $10^{\text {th }}$ of transduction revealed a significantly higher $(P<0.05)$ number of $\mathrm{GFP}^{+}$bFFs treated with $\geq 1.5$ mM VPA as compared to VPA untreated cells (Fig. 3C). Further, it was observed that, $1.5 \mathrm{mM}$ VPA treatment resulted in maximum number of $\mathrm{GFP}^{+}$cells (about 5 fold higher than control) (Fig. 3D).

\section{Generation and characterization of iPSC colonies}

At 4-5 d of post transduction, the infected bFFs began to change morphology, started expressing GFP (Fig. 4P) and proliferated rapidly attaining confluence. The confluent cells were further replated in $90 \mathrm{~mm}$ dishes on days 5 and 7 to facilitate the colony formation. Appearance of small ESC like colonies was first observed on 16-18 day post transduction in all the groups with potent GFP expression (Table 2, Fig. 4P). It was noted that VPA treatment significantly increased the number of colony formation except in $3 \mathrm{mM}$ concentration (Table 2) with maximum numbers in $1.5 \mathrm{mM}$ $(\sim 2.5$ fold, $\mathrm{P}<0.05)$ as compared to untreated control. The size of the colonies in all the VPA treated groups was also significantly larger $(P<0.05)$ than control (Table 2) with maximum size in $1.5 \mathrm{mM}$ concentration (Table 2). The typical size of the colonies which were counted (AP positive) and propagated further has been presented in Fig. $4 \mathrm{P}, \mathrm{Q}$. The expression of endogenous pluripotent genes in colonies derived from VPA treated and untreated control bFFs has been presented in Fig. 4R. It was observed that the primary colonies generated from 1.5 mM VPA treated cells had significantly higher expression of Oct4, Sox2, Nanog, and c-Myc than other groups. Because of comparatively higher number, size as well as expression of pluripotent genes, the colonies of 1.5mM VPA treated cells were further propagated.

The colonies appeared from VPA treated $(1.5 \mathrm{mM})$ and untreated control bFFs were picked up on the basis of their morphology and expanded mechanically or by trypsinisation method (Fig. $4 \mathrm{~S}, \mathrm{~T}$ ). We observed that the mechanically dissociated pieces grew into large well defined secondary colonies within 3-4 days of culture. Subsequently, these secondary colonies were further passaged in the same way on every 3-4 days. In trypsinisation method, the secondary colonies were formed after 4-5 days and took another 3-4 days to resume their well defined size suitable for propagation. Subsequently, these secondary colonies were passaged by trypsinisation method and the propagation of subsequent colonies was continuously propagated by the same method.

It was noteworthy that the colonies generated from trans-

Fig. 2.Timeline for the generation of pLentG-VPA induced buffalo induced pluripotent stem cell colonies. 
TABLE 1

\section{PRIMERS USED IN FOR RT-PCR}

\begin{tabular}{|c|c|c|c|}
\hline Gene & Primer & $\begin{array}{c}\text { Annealing } \\
\text { temperature }\left({ }^{0} \mathrm{C}\right)\end{array}$ & Product Size (bp) \\
\hline GAPDH & $\begin{array}{l}\text { F } 5^{\prime} \text { ggagaaacctgccaagtatg } 3^{\prime} \\
\text { R5 ' tgagtgtcgctgttgaagtc } 3^{\prime}\end{array}$ & 65 & 126 \\
\hline Oct 4 & $\begin{array}{l}\text { F 5'-caatttgccaagctcctaaag-3' } \\
\text { R 5'- gcctctcactcggttctc-3' }\end{array}$ & 55 & 288 \\
\hline Sox2 & $\begin{array}{l}\text { F 5'-cggcaaccagaagaacag-3' } \\
\text { R 5'-cggcagtgtgtacttatcc-3' }\end{array}$ & 60 & 292 \\
\hline Nanog & $\begin{array}{l}\text { F 5'-gtcccggtcaagaaacaaaa-3' } \\
\text { R 5'-tgcatttgctggagactgag-3' }\end{array}$ & 60 & 107 \\
\hline Klf4 & $\begin{array}{l}\text { F 5'-gaactgaccaggcactac-3' } \\
\text { R 5'-ctgattatccattcacaagttg-3' }\end{array}$ & 55 & 271 \\
\hline c-Myc & $\begin{array}{l}\text { F 5'-ttgctcttcgtgaccag-3' } \\
\text { R 5'-tgcccaaagttccatttg-3' }\end{array}$ & 60 & 400 \\
\hline Fox D3 & $\begin{array}{l}\text { F 5'-agcaagcccaagaatagc-3' } \\
\text { R 5'-tccagggtccagtagttg-3' }\end{array}$ & 55 & 257 \\
\hline pLentG-Oct4 & $\begin{array}{l}\text { F5'-accatgtttctgaagtgccc-3' } \\
\text { R5'-ctgggaaaggtgtccctgta-3' }\end{array}$ & 55 & 181 \\
\hline pLentG-KIf4 & $\begin{array}{l}\text { F5'-gtgcagcttgcagcagtaac-3' } \\
\text { R5'-ggaagacgaggatgaagctg-3' }\end{array}$ & 55 & 164 \\
\hline Nestin & $\begin{array}{l}\text { F-5'-aacgctgagtcattgagaac-3' } \\
\text { R-5'-cactgcctcctggtcttc-3' }\end{array}$ & 65 & 276 \\
\hline BMP4 & $\begin{array}{l}\text { F-caggctaccaggcattctac-3' } \\
\text { R-accaccttgtcatactcatcc-3' }\end{array}$ & 60 & 190 \\
\hline CDX2 & $\begin{array}{l}\text { F-5'-aacctgtgcgagtggatg-3' } \\
\text { R-5'-ctgttgctgctgctgttg-3' }\end{array}$ & 60 & 276 \\
\hline
\end{tabular}

A

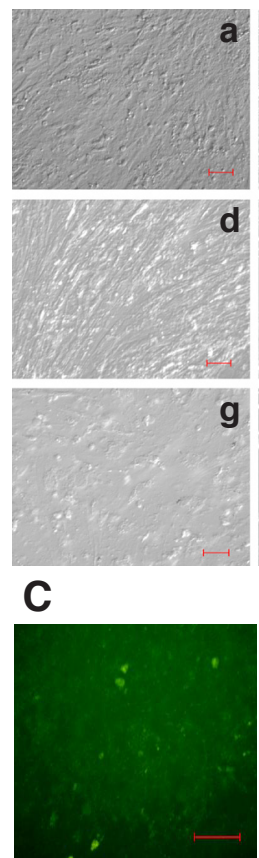

$\operatorname{Tr}+\operatorname{SCM}$

D

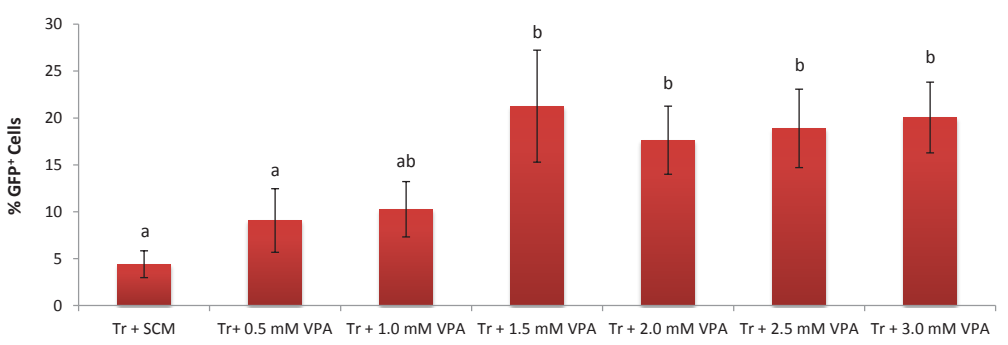

\section{B}

ducted bFFs resembled buffalo ESC like morphology and therefore we termed them buffalo iPSC like cells (BuiPSCs). We also observed that more number of colonies was developed from unit colony of VPA treated group both in trypsinisation (2.69 vs. 1.56) and mechanical dissociation ( 2.69 vs. 2.04 colonies) method than control. Further, the size of colonies generated through mechanical dissociation was significantly larger $(p<0.05)$ than that of colonies obtained through trypsinisation (Table 3 ).

\section{Characterisation of BuiPSCs}

The colonies during propagation were positive for alkaline phosphatase staining (Fig. 5 A,B) with normal chromosome numbers (Fig. 5C). Immunofluorescence staining of P0 colonies of different treatment groups showed that they were immunopositive for pluripotency markers Oct4, Nanog, SSEA-1, TRA-1-60 and TRA1-81(Fig. 5D). The colonies also expressed pluripotency genes Oct4, Nanog, Sox2, Klf4 and c-Myc (Fig. 4R).

When we compared the relative abundance of pluripotent genes in colonies on different passages, it was observed that the expression of all the genes were declined gradually on subsequent passages (Fig. 6 A,B) which may be the reason that the BuiPSCs colonies could be propagated up to passage 18 only. Further, expression of the exogenous pluripotent genes (Oct4 and Klf4) was detected at passage 10 which was undetected in passage 15 (Fig. 6C) suggesting silencing of these exogenous genes.

The reprogrammed cells readily formed embryoid bodies (EBs) (Fig. 6D). RT-PCR analysis of EBs detected expressions of

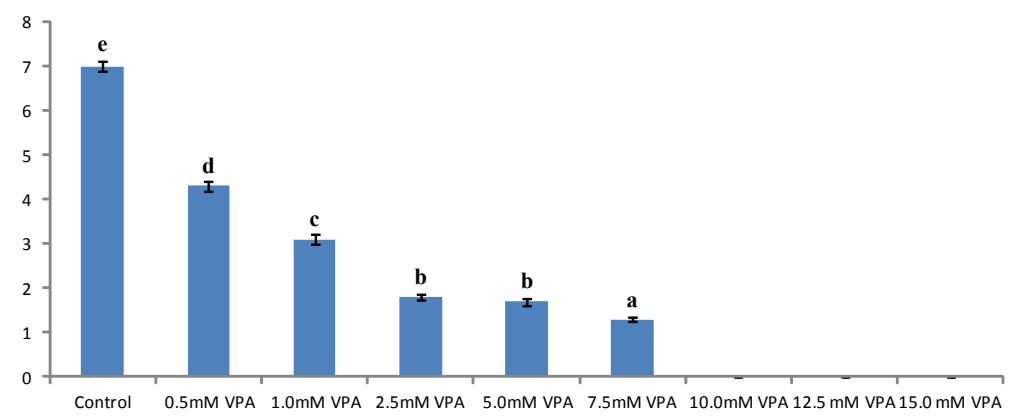

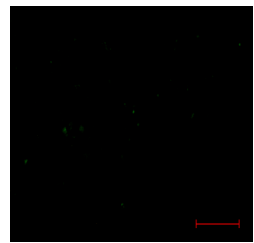

Tr + 1.5 mM VPA

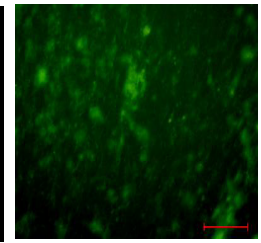

$\operatorname{Tr}+2.0 \mathrm{mM} \mathrm{VPA}$

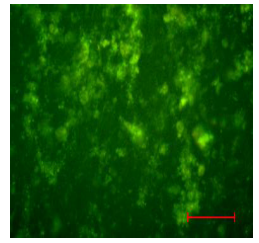

$\operatorname{Tr}+2.5 \mathrm{mM} \mathrm{VPA}$



$\operatorname{Tr}+3.0 \mathrm{mM} \mathrm{VPA}$
Fig. 3.The effect of valproic acid (VPA) treatment on uninfected buffalo fetal fibroblasts (bFF) and bFF transfected with pLentG-KOSM (A) (a-i) Changed morphologies of bFFs and bFFs treated with $0.5,1,2.5,5,7.5,10,12.5$ and $15 \mathrm{mMVPA}$, respectively. (B) Relative cell numbers of bFFs after 7 days of culture with different concentrations of VPA. (C) Representative pictures showing GFP expression by transducted cells (Scale bar: $100 \mu \mathrm{m}$ ). (D) Percentage of GFP+ bFFs measured by FACS analysis at 10 daya post transduction. Means bearing different superscript differ significantly $(p<0.05)$ with respect to each other. 
TABLE 2

\section{NUMBER AND SIZE OF PLENTG AND PLENTG-VPA INDUCED BUFFALO IPSC COLONIES}

\begin{tabular}{|c|c|c|c|c|}
\hline $\begin{array}{l}\text { Culture } \\
\text { System }\end{array}$ & $\begin{array}{l}\text { Initiation } \\
\text { of colony } \\
\text { formation }\end{array}$ & $\begin{array}{c}\text { Total no } \\
\text { of colonies } / 50,000 \\
\text { transducted cells }\end{array}$ & $\begin{array}{c}\text { Average } \\
\text { no of colonies / } \\
\text { microscopic field }\end{array}$ & Colony area $\left(\mu \mathrm{m}^{2}\right)$ \\
\hline No VPA & $18^{\text {th }}$ day & $\begin{array}{c}72.50 \pm 14.29^{\mathrm{ab}} \\
(41-127)\end{array}$ & $\begin{array}{c}8.22 \pm 1.16^{\text {ac }} \\
(4-14)\end{array}$ & $26410.11 \pm 3437.65^{a}$ \\
\hline $1.0 \mathrm{mM}$ VPA & $16^{\text {th }}$ day & $\begin{array}{c}87.67 \pm 18.84^{b} \\
(44-157)\end{array}$ & $\begin{array}{c}6.44 \pm 0.88^{a b} \\
(3-9)\end{array}$ & $38971.87 \pm 4626.81^{b}$ \\
\hline $1.5 \mathrm{mM}$ VPA & $16^{\text {th }}$ day & $\begin{array}{c}176.67 \pm 37.66^{c} \\
(81-283)\end{array}$ & $\begin{array}{c}11.00 \pm 1.50^{\circ} \\
(6-18)\end{array}$ & $44674.17 \pm 3735.43^{b}$ \\
\hline $2.0 \mathrm{mM}$ VPA & $17^{\text {th }}$ day & $\begin{array}{c}91.00 \pm 16.40^{b} \\
(52-144)\end{array}$ & $\begin{array}{c}7.22 \pm 0.94^{\mathrm{a}} \\
(3-11)\end{array}$ & $37359.33 \pm 4151.04^{b}$ \\
\hline $3.0 \mathrm{mM}$ VPA & $18^{\text {th }}$ day & $\begin{array}{c}22.00 \pm 4.62^{a} \\
(9-36)\end{array}$ & $\begin{array}{c}3.67 \pm 0.55^{b} \\
(2-6)\end{array}$ & $38033.25 \pm 3685.13^{b}$ \\
\hline
\end{tabular}

Means bearing different superscripts in a column differ significantly $(p<0.05)$.

$\mathbf{P}$
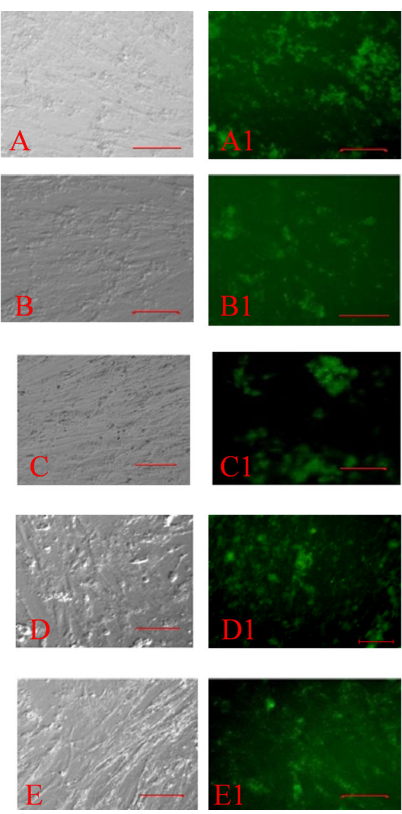

Q


$\mathbf{R}$
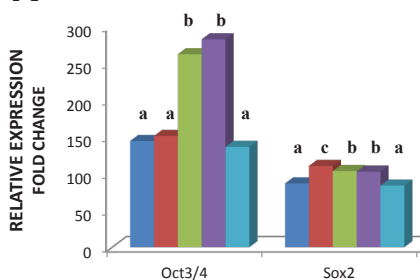

S
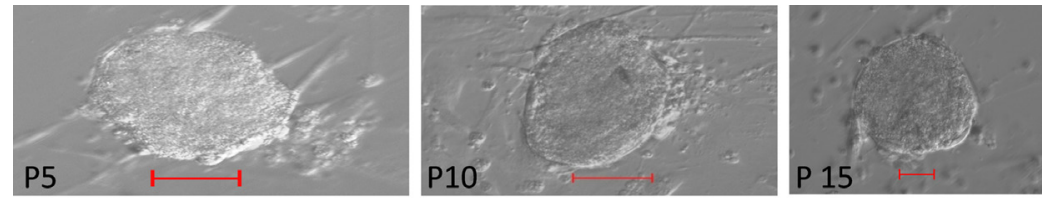

$\mathbf{T}$
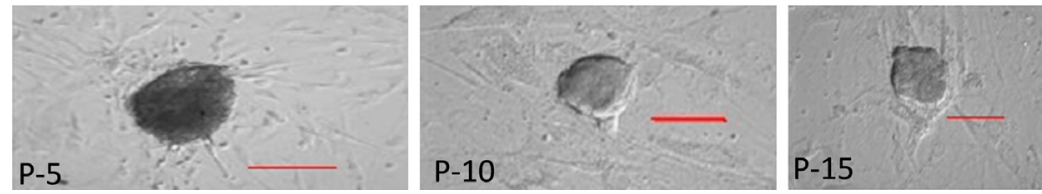


lineage-specific genes representing the cells of three germ layers: ectoderm-Nestin, mesoderm-BMP4 and endoderm-CDX2 (Fig.6E).

\section{Discussion}

There are established technical protocols to reprogram somatic cells into iPSCs in different animal species (Honda et al., 2010). In buffalo, attempts have been made to produce iPSC by reprogramming fetal fibroblast cells. However, the reprogramming efficiency has been quite low, the number of iPSC colonies developed was very less and the reprogrammed cells could not be propagated beyond $10^{\text {th }}$ passage (Deng et al., 2012, Bag et al., 2012). Therefore, in the present study, small molecule valproic acid was used to enhance the reprogramming efficiency of fetal fibroblast cells as well as propagation of iPSC colonies. We observed that treatment of bFFs with $1.5 \mathrm{mM}$ VPA increased about 5 fold $\mathrm{GFP}^{+}$cells



(Fig. 3D) and consistent with this, about 2.5-fold increase of GFP+ colonies was observed compared to control-infected bFFs without treatment (Table 2) indicating a substantial enhancement of VPA induced reprogramming. This allowed us picking more number of colonies within 3 weeks post-infection. Earlier, Huangfu and his coworkers had shown that small molecules greatly improved the efficiency of reprogramming (>100 fold) in mouse and human embryonic fibroblasts (Huangfu et al., 2008a, b). We further observed that although the reprogramming efficiency was higher in different concentration $(1,2$, and $3 \mathrm{mM}$ ) of VPA treatment, but

Fig. 4. Generation of buffalo induced pluripotent stem cell (BuiPSC)-like colonies. (A-A ${ }^{1}$, B-B1, C-C1, D-D1, E-E1 of (P) show the morphology of buffalo fetal fibroblasts (bFFs) and expression of GFP by bFFs on $4^{\text {th }}$ day of transfection. (A2-A3, B2-B3, C2-C3, D2-D3, E2-E3) of $\mathbf{( P )}$ represent colony formation and GFP expression on day $18^{\text {th }}$ post-transfection along with valproic acid (VPA) treatment (0, 1, 1.5, 2 and $3 \mathrm{mM}$, respectively). (A4-A6, B4-B6, C4-C6, D4-D6, E4-E6) of (P) represent multiple colony formation on day 21 post-transfection along with VPA treatment $(0,1,1.5,2$ and 3. $m M$, respectively). (Q) Primary colonies $(P 0)$ expressing mild alkaline phosphatase (AP) activity; (R) relative expression of pluripotent genes in PO colonies generated from VPA treated cells $(1,1.5,2$ and $3 \mathrm{mM})$ where colonies of similar passages derived from VPA untreated cells were taken as control; $(\mathbf{S}, \mathbf{T})$ BuiPSC colonies during different passages through mechanical as well as trypsinisation methods, respectively. Scale bar, $50 \mu \mathrm{m}$. 


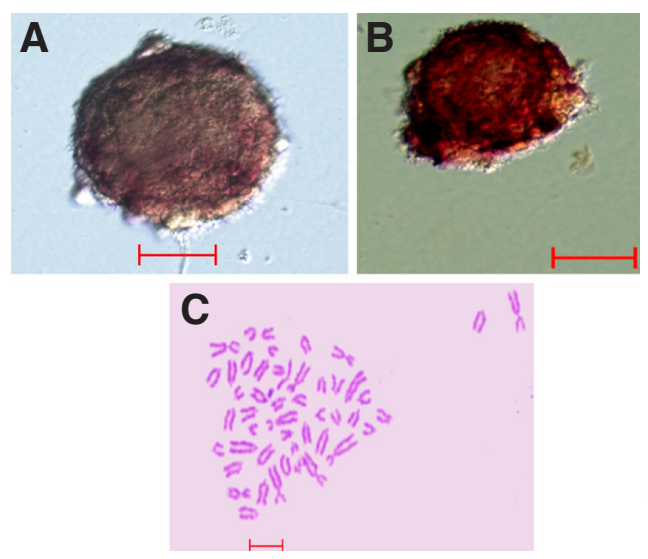

Fig. 5. Characterisation of buffalo induced pluripotent stem cells (BuiPSCs). (A,B) Alkaline phosphatase (AP) activity at passages 0 and 10, respectively. (C) Normal karyotype of buffalo iPSCs at passage 12 (D) Immunofluoroscence staining shows expression of pluripotency markers Oct4, Nanog, Tra-1-60Tra-1-81 and SSEA-1 in pLentG (NT) and pLentG-VPA induced buffalo iPSC colonies. Scale bar: $100 \mu \mathrm{m}$.
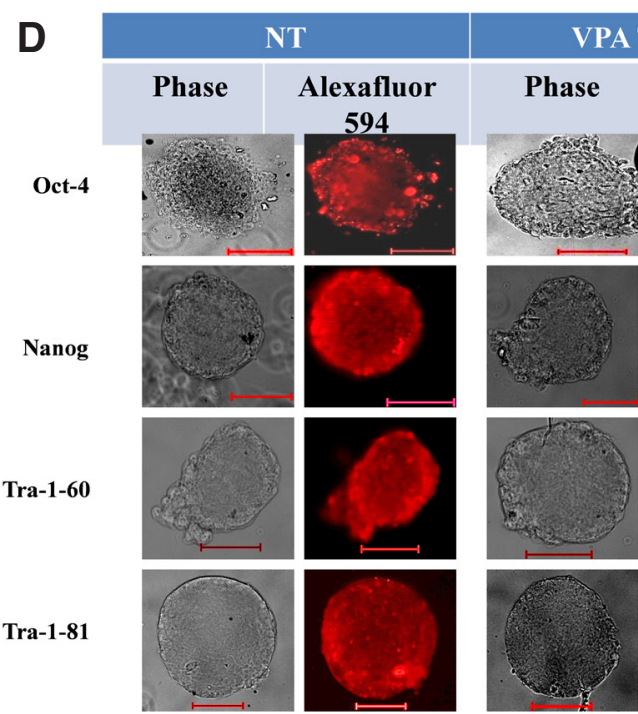

\section{Treated}
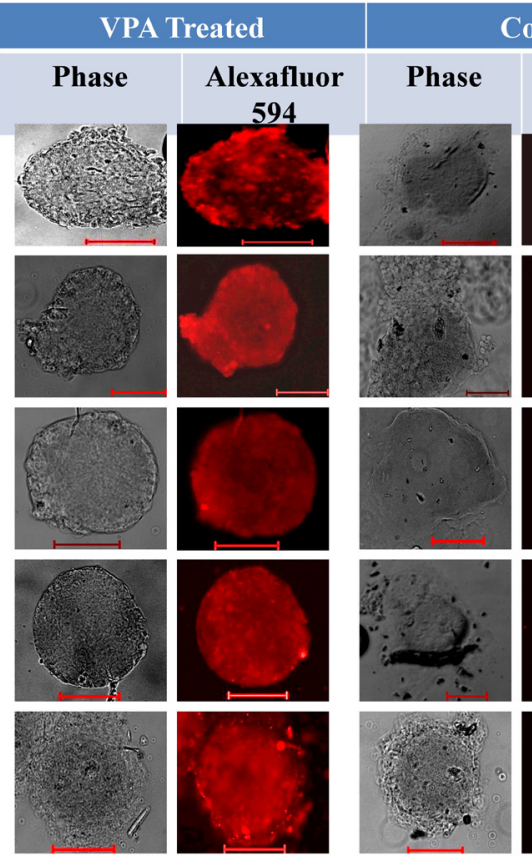

Control



the number and size of subsequent colony formations was lower (Table 2). This may be due to suboptimal (1 mM) or toxic $(2,3 \mathrm{mM})$ level of valproic acid (Huangfu et al., 2008a).

In recent times several pharmacological agents have been shown to enhance in vitro and in vivo gene expression delivered through viral vectors. VPA has been shown to increase and extend the expression of exogenous genes in a wide range of transduced cells with different gene transfer agents including viruses (Shongshan et al., 2005). This biological activity has been attributed with VPA's ability to function as a histone deacetylase inhibitor (HDACi). Recently it has been observed that VPA directly regulate pluripotent Oct4 gene expression to ensure the acquirement and maintenance of pluripotency (Han et al., 2011). Further, it has been reported that VPA is required for reprogramming mouse fibroblasts by specifically degrading HDAC2 protein, a finding that is supported by the efficient reprogramming of HDAC2 ${ }^{-}-$fibroblasts in the absence of VPA(Frederick etal., 2011). However, it has also been demonstrated that VPA alone cannot reprogram mouse fibroblast while induced a transcriptional program that can be described as leaning toward an ES-like pattern (Huangfu et al., 2008b).

In the present study, the morphology of BuiPSCs resembled buffalo ESC (Sharma et al., 2011). Further, passaging of BuiPSCs colonies by mechanical dissociation produced significantly larger size of colonies than trypsinisation method (Fig. 4S, Table 3). We propose that BuiPSCs colony may be propagated in better way by mechanical dissociation method. The silencing of exogenous pluripotent genes in BuiPSCs was not observed until $10^{\text {th }}$ passage. However, silencing of transgenes as early at passage 6 has been reported (Deng et al., 2012). Prolong expression of transgenes in the present study may be due to the use of lentiviral vector, which resulted in poor silencing of exogenous genes (Lois et al., 2002).

In the present study, mouse defined factors were successful in reprogramming bFFs as has been documented in fibroblasts of pig (Ezashi et al., 2009, Wu et al., 2009), sheep (Bao et al., 2011), horse (Nagy et al., 2011) and buffalo (Bag et al., 2012). Similarly, buffalo defined factors have successfully reprogrammed mouse fetal fibroblasts Deng et al.,2012). This indicates that reprogramming factors are conserved among species.

The BuiPSCs expressed pluripotent markers, readily formed embryoid bodies and differentiated into cells of three germ layers which are important characteristics of pluripotent cells. We observed that VPA treatment in bFFs had enhanced the endogenous expression of Oct4, Nanog and SOX2 in iPSC colonies as compared to VPA untreated control (Fig. 6A,B) which indicated better reprogramming of bFFs by VPA, as these genes play a crucial role in repressing differentiation, promoting self-renewal and maintaining survival of ESC (Liu et al., 2012).

In the present study, BuiPSCs could be propagated up to $18^{\text {th }}$ passage only. We observed that the expression of endogenous pluripotent genes was significantly higher at initial passages which

TABLE 3

\section{NUMBER AND SIZE OF IPSC COLONIES DEVELOPED BY TRYPSINISATION AND MECHANICAL DISSOCIATION METHODS}

\begin{tabular}{|c|c|c|c|c|c|c|c|}
\hline Culture Systems & & $\begin{array}{l}\text { Total No. } \\
\text { of colonies trypsinized } \\
\text { / mechanically cut }\end{array}$ & $\begin{array}{c}\text { Cut piece } \\
\text { colonies obtained } \\
\text { by mech. dissociation }\end{array}$ & $\begin{array}{l}\text { Total No. } \\
\text { of colonies generated } \\
\text { from splitted colonies }\end{array}$ & $\begin{array}{l}\text { Colonies generated/ } \\
\text { splitted colony }\end{array}$ & $\begin{array}{l}\text { Percentage } \\
\text { generation }\end{array}$ & Area of colony $\left(\mu \mathrm{m}^{2}\right)$ \\
\hline $\begin{array}{l}\text { No VPA treatment } \\
\text { VPA treatment }\end{array}$ & $\begin{array}{l}\text { Trypsinised into } \\
\text { single cell }\end{array}$ & $\begin{array}{l}85 \\
83\end{array}$ & $\begin{array}{l}- \\
-\end{array}$ & $\begin{array}{l}133 \\
224\end{array}$ & $\begin{array}{l}1.56 \\
2.69\end{array}$ & $\begin{array}{l}156.47 \\
269.88\end{array}$ & $\begin{array}{l}47724.75^{\mathrm{a}} \pm 5486.01 \\
52326.86^{\mathrm{a}} \pm 5328.01\end{array}$ \\
\hline VPA treatment & Mechanical dissociation & 50 & 168 & 102 & 2.04 & 204.00 & $79529.82^{b} \pm 10573.56$ \\
\hline
\end{tabular}

Means bearing different superscript in a column differ significantly $(p<0.05)$. 
A

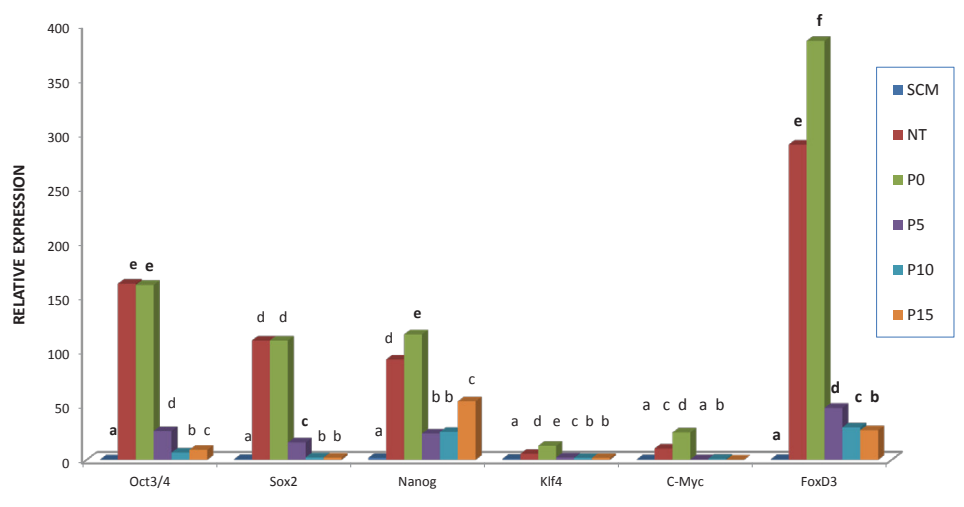

B

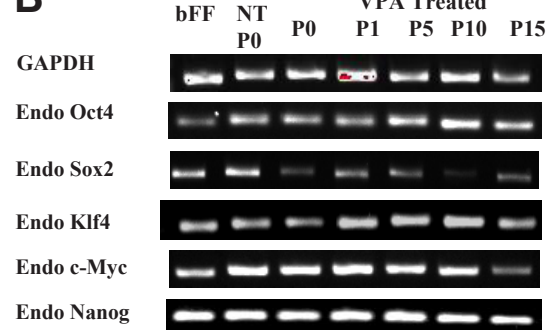

D

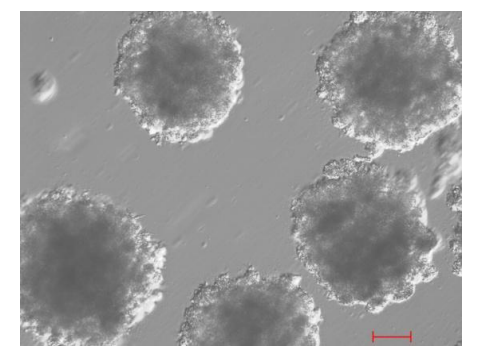

C

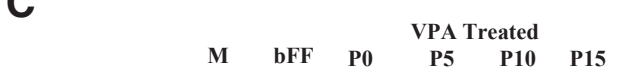

GAPDH

pLentG Oct4

pLentG Klf4

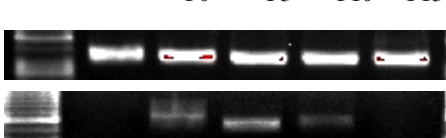

-

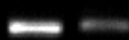

E

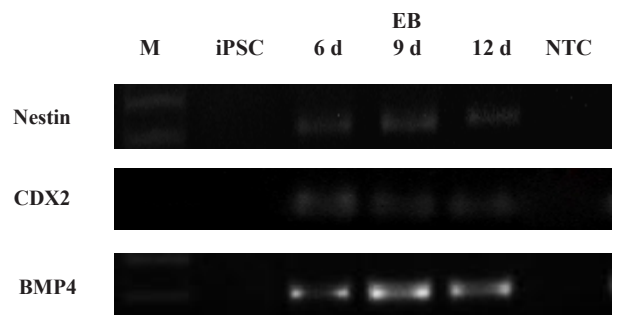

buffalo fibroblast. The effort will provide a better approach in establishing a buffalo iPSC line to carry out experiments involving modification of large animal genome.

\section{Materials and Methods}

The experiment was approved by the Animal Ethics Committee of Indian Veterinary Research Institute, Bareilly, India in accordance with the care and use of animals for scientific purposes.

\section{Plasmid preparation and lentivirus pack- aging}

pLentG-KOSM plasmid (LTV 700, Cell Biolabs), which carries murine defined factors Oct4, Sox2, Klf4 and c-Myc in a single open reading frame (ORF) and controlled by a CMV promoter was used for the study. The ORF is followed by IRES (Internal Ribosome Entry Site) and a reporter gene GFP. About $10 \mu$ l of bacterial glycerol stock of plasmid was streaked on LB (Luria-Bertani) agar and incubated overnight at $37^{\circ} \mathrm{C}$. The bacterial colonies were picked up next day and again grown overnight on LB broth in a shaker incubator. The plasmid DNA was extracted from the bacteria using Mini-prep and Maxi prep culture kit as per the manufacturer's protocol (MIPK- 0250 and QXEK-0025, MDI).

The production of virus particles has been presented in Fig.1. In brief, the pseudovirus was produced in 293T cells by transient transfection with pLentG-KOSM plasmid vector and a mixture of three helper plasmids; pRSV-Rev packaging vector, pCMV-VSV-G envelope vector and $\mathrm{pCgpV}$ packaging vector (ViraSafe $^{\mathrm{TM}}$ Lentiviral Packaging System, Cell Biolabs) using Lipofectamine 2000 (Invitrogen) as transfection reagent. The viral supernatants were collected at $48 \mathrm{~h}$ and $60 \mathrm{~h}$ post transfection and used for the study.

\section{Isolation and culture of buffalo fetal fibro- blasts (bFFs)}

The uterus containing buffalo fetus $(\sim 70-80$ days old) was aseptically collected from local gradually decreased and were low at passage 15 indicating gradual differentiation of BuiPSCs. This gradual differentiation and failure of propagation of cells beyond $18^{\text {th }}$ passage may be due to the suboptimal culture condition of the present study. Derivation and maintenance of ESC from domestic animal has been a problem (Liu et al., 2012, Cebrian-Serrano et al., 2013) primarily due to absence of an optimised culture media which is available for mice and human iPSC. Thus, in future, optimisation of in vitro culture condition for self renewal and long term propagation of BuiPSCs should be done. However, this is by far the highest number of passages of BuiPSCs achieved in the present study.

\section{Conclusion}

The results of this study indicated that small molecule VPA at lower doses can significantly improve reprogramming efficiency of

slaughter house and thoroughly washed with sterile normal saline solution supplemented with gentamicin $(50 \mu \mathrm{g} / \mathrm{ml})$. After swabbing the entire uterus with $70 \%$ ethyl alcohol, the amniotic sac and fetus were transferred to a sterile beaker containing phosphate buffered saline (PBS). A skin sample was aseptically collected from the abdominal region of the fetus. bFFs derived from the skin sample were cultured in Dulbecco's Modified Eagle's Medium (DMEM, Life Technologies) supplemented with 10\% fetal bovine serum (FBS, Gibco), 1\% L-glutamine (200 mM, Gibco) and 1\% streptopenicillin (Sigma-Aldrich). Fibroblasts derived from the second subculture were used for reprogramming.

\section{Determination of valproic acid tolerance of bFFs}

Wells of a sterile six well tissue culture plate coated with $0.1 \%$ gelatin were seeded with approximately $1.0 \times 10^{5} \mathrm{bFFs}$ at passage 2 in fibroblast media (FM: DMEM supplemented with 10\% FBS, 1\% L-glutamine and $1 \%$ streptopenicillin). The cells were treated with different concentrations of VPA (0.5mM, 1.0 mM, 2.5 mM, 5.0 mM, $7.5 \mathrm{mM}, 10.0 \mathrm{mM}, 12.5 \mathrm{mM}$ and $15.0 \mathrm{mM}$ ) in media after formation of monolayer (day 0 ) and the media was 
supplemented every second day till day 7 of culture. The morphology and survivability of cells were determined to assess different dose of VPA where $\leq 3 \mathrm{mM}$ VPA was found to be well tolerated by bFFs and subsequently the bFFs were treated within these doses during reprogramming.

\section{Generation and maintenance of iPSCs}

For reprogramming, the viral transduction and VPA treatment of bFFs was done as per the method described by Takahashi and Yamanaka (2006) and Huangfu et al.,2008b) with slight modification. Briefly, approximately 0.5 $x 10^{5}$ numbers of bFFs were seeded in each gelatin coated well of sterile six well tissue culture plate using FM. The cells were co-infected with lentivirus and ViraDuctin ${ }^{\mathrm{TM}}$ Lentivirus transducting System (Cell Biolabs) at 24 $\mathrm{h}$ of plating. After overnight incubation, the transducted cells were washed twice with FM to remove the viral supernatant followed by supplementation with stem cell media (SCM) and kept undisturbed for $72 \mathrm{~h}$ at $37^{\circ} \mathrm{C}$ under $5 \% \mathrm{CO}_{2}$. The SCM contained knockout DMEM/F12 (Life Technologies) supplemented with $20 \%$ FBS, $1 \%$ L-glutamine, $1 \%$ streptopenicillin, $1 \%$ nonessential amino acid (Gibco), $0.1 \mathrm{mM} \mathrm{b}$-mercaptoethanol, $4 \mathrm{ng} / \mathrm{ml}$ of human leukemia inhibitory factor (Sigma- Aldrich) and $4 \mathrm{ng} / \mathrm{ml}$ of basic fibroblast growth factor (Sigma- Aldrich). From $4^{\text {th }}$ day post transduction, VPA (1.0 mM, $1.5 \mathrm{mM}, 2.0 \mathrm{mM}$ and $3.0 \mathrm{mM}$ ) was supplemented in SCM for 1 week with change of media on every $2^{\text {nd }}$ day. After VPA treatment, the cells were maintained for next 15 days in SCM alone for development of colonies. On $10^{\text {th }}$ day post transfection, FACS analysis was done to observe the number of GFP+ ${ }^{+}$cells. Thereafter, the colonies with ESC-like morphology were counted till $27^{\text {th }}$ day post transduction to compare the efficiency of the induction system.

The primary colonies (P0) of 1.5mM VPA treated as well as VPA untreated control were further propagated and characterized. For propagation, two methods were followed. Some colonies were trypsinized into single cells and others were mechanically cut into 3-5 small pieces depending on the size of the colony. The splitted cells as well as small pieces (3-5 numbers) were put on the mitomycin-c inactivated bFFs in SCM. The detail protocol of iPSC generation has been presented in Fig. 2. The reprogramming efficiency was calculated as the number of iPSC colonies formed per total number of cells transducted.

\section{Alkaline phosphatase staining and Immunofluorescence assay}

To detect AP activity, colonies were isolated mechanically and fixed on glass slides under stereo microscope with $4 \%$ paraformaldehyde for $20 \mathrm{~min}$ at room temperature. The colonies were washed twice PBS and stained with $0.5 \mathrm{mg} / \mathrm{ml}$ naphthol AS-MX phosphate (Sigma- Aldrich) and $1 \mathrm{mg} / \mathrm{ml}$ FAST RED TR salt (Sigma-Aldrich) in $100 \mathrm{mM}$ tris buffer ( $\mathrm{pH}$ 8.2) for $4 \mathrm{~h}$ at room temperature as per standard protocol (Moore and Piedrahita, 1997). The stained colonies were examined under inverted microscope (Olympus).

The iPSCs colonies were characterized by immunocytochemistry using ESC specific markers Oct-4, Nanog, TRA-1-60, TRA-1-81 and SSEA-1 as per the methods of National Institutes of Health, resource for stem cell research, USA using Alexa Fluor 594 (AF 594) conjugated antibody.

\section{Chromosomal numbers during propagation}

The iPSC colonies at $12^{\text {th }}$ passage were arrested in metaphase by exposing them to $0.02 \mu \mathrm{g} / \mathrm{ml}$ colcemid (Sigma-Aldrich) for $4 \mathrm{~h}$ in a humidified atmosphere of $5 \% \mathrm{CO}_{2}$ in air at $37^{\circ} \mathrm{C}$, and then resuspended in $0.56 \%$ $\mathrm{CaCl}_{2}$ for $30 \mathrm{~min}$ at $37^{\circ} \mathrm{C}$. After centrifugation at $400 \mathrm{~g}$ for $5 \mathrm{~min}$, cells were fixed with $4 \mathrm{ml}$ of acetic acid and methanol (1:3) solution for $20 \mathrm{~min}$ at $37^{\circ} \mathrm{C}$. Thereafter, chromosome spreads were prepared by dropping cell suspension onto cold slides and allowed to dry. At last, the slides were stained with $10 \%$ Giemsa solution for 15 min and analyzed under oil immersion using Olympus microscope.

\section{Preparation of embryoid bodies}

The iPSC colonies at $12^{\text {th }}$ passage were trypsinized into single cells and cultured in low attachment Petridish in the presence of differentiation medium to form embryod bodies (EBs). The differentiation medium con- sists of high glucose IMDM (Gibco), supplemented with 10\% FBS, $2 \mathrm{mM}$ L-glutamine, $1 \%$ nonessential amino acid, $0.1 \mathrm{mM}$ b-mercaptoethanol and gentamicin $50 \mu \mathrm{g} / \mathrm{ml}$. The EBs were further cultured in differentiation medium and harvested on 6,9 and $12^{\text {th }}$ day to examine the expression of Nestin (ectoderm), BMP4 (mesoderm) and CDX2 (endoderm) representing 3 embryonic germ layers as described below.

\section{Molecular characterization and relative expression of pluripotent marker genes}

The relative expression of pluripotent genes was analysed in P0 colonies generated from VPA treated cells $(1.0 \mathrm{mM}, 1.5 \mathrm{mM}, 2.0 \mathrm{mM}$ and $3.0 \mathrm{mM}$ ) where colonies of similar passages derived from VPA untreated cells were taken as control. Similarly, expression of exogenous (pLentG Oct4, pLentG Klf4) and endogenous (Oct4, Nanog, Sox2, Klf4 and c-Myc) pluripotent genes in colonies of $1.5 \mathrm{mM}$ treated cells was also studied during different passages (P0, P5, P10 and P15) and P0 cells was taken as reference sample for gene expression analysis. Individual sample of BuiPSCs colonies ( 9 numbers) and EBs (7 numbers) were collected from at least three independent experiments for analysis. All the samples were kept frozen until further analysis.

The total RNA was isolated from all the samples using the mini RNA kit (Zymo Research, USA) as per manufacturer's instruction. The cDNA was synthesized using fixed amount of isolated RNA by using CDNA synthesis kit (iScript, Biorad, USA). Amplification of genes was performed using gene-specific primers (Table 1) and Eva Green supermix (Biorad, USA) as per manufacturer's instructions. The PCR reaction included an initial denaturation at $95^{\circ} \mathrm{C}$ for 30 s followed by 40 cycles of denaturation at $95^{\circ} \mathrm{C}$ for 30s, annealing at $65^{\circ} \mathrm{C}$ (GAPDH and Nestin), $60^{\circ} \mathrm{C}$ (Sox2, Nanog, CMyc, BMP4 and CDX2) and at $55^{\circ} \mathrm{C}$ (Oct4 and KIf4) for 10s. Internal control RT-PCR reactions used a primer set specific for the cellular housekeeping gene, glyceraldehyde-3-phosphate dehydrogenase (GAPDH). To ensure the specificity of target amplification, melting curves and agarose $(2 \%)$ gel electrophoresis of the PCR reactions were performed. The relative mRNA expression of genes was calculated using the $2^{-\triangle \Delta C T}$ method (Livak and Schmittgen, 2001) and the results were expressed as a fold change in expression over the control. The samples of at least three experiments were analyzed for gene expression studies.

\section{Statistical analysis}

The data generated was analyzed for ANOVA using statistical package SPSS-16.0 adopting standard statistical procedures (Snedecor and Cochran, 1994).

\section{Acknowledgements}

The authors are thankful to ICAR and Director, IVRI for providing all the facilities to carry out the present research work.

\section{References}

BAG S, YASOTHAT, KUMAR M, KUMAR K, SINGH RAND MAHAPATRAPS (2012). Generation of induced pluripotent stem cells in buffalo using murine defined factors. Stem cells and clinical applications, 7th Annual Congress of the German Society for Stem Cell Res pp 60 (Abstr.)

BAO L, HE L, CHEN J, WU Z, LIAO J, RAO L, REN J, LI H, ZHU H, QIAN L, GU Y, HIA H, XU X, ZHOU J, WANG W, CUI C and XIAO L (2011). Reprogramming of ovine adult fibroblasts to pluripotency via drug-inducible expression of defined factors. Cell Res 21: 600-608.

CEBRIAN-SERRANO A, TOM S and ANDRAS D (2013).Veterinary applications of induced pluripotent stem cells: Regenerative medicine and models for disease? The Vet J 198: 34-42.

DENG Y, LIU Q, LUO CHAN, CHEN S, LI X, WANG C, LIU Z, LEI X, ZHANG H, SUN H, LU F, JIANG J and SHI D (2012). Generation of induced pluripotent stem cells from buffalo (Bubalus bubalis) fetal fibroblasts with buffalo defined factors. Stem Cells Dev 21: 2485-2494.

ESTEBAN M A, WANG T, QIN B, YANG J, QIN D and CAI J (2010). Vitamin C 
enhances the generation of mouse and human induced pluripotent stem cells. Cell Stem Cell 6: 71-79.

EZASHI T, TELUGU B P, ALEXENKO A P, SACHDEV S, SINHA, S and ROBERTS $\mathrm{R} M$ (2009). Derivation of induced pluripotent stem cells from pig somatic cells. Proc Natl Acad Sci USA 106: 10993- 98.

FREDERICK A, CHINMAY MT, DENISE J, MUDIT G, ZHENG C, YING T, YUZHEN Z, WENLI Y, PETER JG, JONATHAN AE AND EDWARD EM (2011). Highly Efficient miRNA-Mediated Reprogramming of Mouse and Human Somatic Cells to Pluripotency. Cell Stem Cell 8: 376-388.

HAN X, HAN J, DING F, CAO S, LIM SS, DAI Y, ZHANG R, ZHANG Y, LIM B and L $N$ (2011). Generation of induced pluripotent stem cells from bovine embryonic fibroblast cells. Cell Res 21: 1509-1512.

HONDAA, HIROSE M, HATORI M, MATOBA S, MIYOSHI H, INOUE K and OQURA $A$ (2010). Generation of induced pluripotent stem cells in rabbits: potential experimental models for human regenerative medicine. J Biol Chem 285:31362-31369.

HONG H, TAKAHASHI K, ICHISAKA T, AOI T, KANAGAWA O and NAKAGAWA M (2009). Suppression of induced pluripotent stem cell generation by the p53-p21 pathway. Nature 460: 1132-1135.

HUANGFU D, MAEHR R, GUO W, EIJKELENBOOM A, SNITOW M, CHEN A E and MELTON DA (2008a). Induction of pluripotent stem cells by defined factors is greatly improved by small-molecule compounds. Nat Biotechnol 26: 795-797.

HUANGFU D, OSAFUNE K, MAEHR R, GUO W, EIJKELENBOOM A, CHEN S, MUHLESTEIN W and MELTON D A (2008b). Induction of pluripotent stem cells from primary human fibroblasts with only Oct4 and Sox2. Nat Biotechnol26: 12691275. HAN FT, YU-LIANG K, MOO RL, CHUNG LL, TA WC, HSIEN S, HANG SL, KWANG HL AND SHEN LC (2010). Valproic acid enhances Oct4 promoter activity in myogenic cells. J Cell. Biochem 110: 995-1004.

LIU J, DEEPASHREE B, BELINDA M, JENNIFER M. K, HUSEYIN S and VERMA $P J$ (2012). Generation and characterization of reprogrammed sheep induced pluripotent stem cells. Theriogenology 77: 338-346.

LIVAK K J, SCHMITTGEN T D (2001). Analysis of relative gene expression data using real-time quantitative PCR and the $2^{-\Delta \Delta C T}$ Method. Methods 25: 402-408.
LOIS C, HONG E J, PEASE S, BROWN EJ and BALTIMORE D (2002). Germ line transmission and tissue specific expression of transgenes delivered by lentiviral vectors. Science 295: 868-872

MOORE K, PIEDRAHITA J A (1997). The effects of human leukemia inhibitory factors (HILF) and culture medium on in vitro differentiation of cultured porcine inner cell mass. In Vitro Cell Dev Biol 33: 62-71.

NAGYK, SUNG HK, ZHANG P, LAFLAMME S, VINCENT P, AGHA-MOHAMMADI S, WOLTJEN K, MONETTI C, MICHAEL IP, SMITH LC and NAQY A (2011). Induced pluripotent stem cell lines derived from equine fibroblasts. Stem Cell Rev7: 693-702.

RENJ, PAK Y, HE L, QIAN Land GUY (2011). Generation of hircine-induced pluripotent stem cells by somatic cell reprogramming. Cell Res 21: 849-853.

SHARMA R, AMAN G, NITIN M K, KARN P S, CHAUHAN M S, SINGLA S K, MANIK R S, AND PALTA P (2011). Optimization of Culture Conditions to Support LongTerm Self-Renewal of Buffalo (Bubalus bubalis) Embryonic Stem Cell-Like Cells. Cell Reprogram 13: 539-549.

SHIMADA H, NAKADA A, HASHIMOTO Y, SHIGENO K, SHIONOYA Y and NAKAMURA T (2010). Generation of canine induced pluripotent stem cells by retrovira transduction and chemical inhibitors. Mol Reprod Dev 77: 2.

SHONGSHAN F, CASEY AM, SERVIO HR, BIRGIT BT, RAMIL S, ZIYE S, SHIKHA C, STEPHEN DEWHURST (2005).Valproic acid enhances gene expression from viral gene transfer vectors. J Virological Methods 125: 23-33.

SNEDECOR GW and COCHRAN WG (1994). Statistical methods. Oxford and IBH publishing Co. Pvt. Ltd., New Delhi.

TAKAHASHI K, YAMANAKAS (2006). Induction of pluripotent stem cells from mouse embryonic and adult fibroblast cultures by defined factors. Cell 126: 663-676.

WU Z, CHEN J, REN J, BAO L, LIAO J, CUI C, RAO L, LI H, GU Y, DAI H, ZHU H, TENG X CHENG L and XIAO $L$ (2009). Generation of pig induced pluripotent stem cells with a drug-inducible system. J Mol Cell Biol 1: 46-54.

YU J, VODYANIK M A, SMUGA-OTTO K, ANTOSIEWICZ-BOURGET J, FRANE J L, TIAN S, NIE J, JONSDOTTIR G A, RUOTTI V, STEWART R, SLUKVIN I I and THOMSON J A (2007). Induced pluripotent stem cell lines derived from human somatic cells. Science 318: 1917-1920. 


\section{Further Related Reading, published previously in the Int. J. Dev. Biol.}

Generation of pluripotent stem cells via protein transduction

Xia Li, Pengfei Zhang, Chao Wei and Yunhai Zhang

Int. J. Dev. Biol. (2014) 58: 21-27

http://dx.doi.org/10.1387/ijdb.140007XL

What scientists would like to tell you about reprogramming (if only they knew!)

Michele Boiani and José B. Cibelli

Int. J. Dev. Biol. (2010) 54: 1541-1543

http://dx.doi.org/10.1387/ijdb.113303mb

Reprogramming cell fate: a scientific journey from viral enhancers to the master gene regulator Oct4 - an interview with Hans R. Schöler

Michele Boiani

Int. J. Dev. Biol. (2010) 54: 1685-1695

http://dx.doi.org/10.1387/ijdb.103248mb

Comparison of reprogramming ability of mouse ES and iPS cells measured by somatic cell fusion

Huseyin Sumer, Craig Nicholls, Jun Liu, Pollyanna A. Tat, Jun-Ping Liu and Paul J. Verma Int. J. Dev. Biol. (2010) 54: 1723-1728

http://dx.doi.org/10.1387/ijdb.103204hs

Porcine induced pluripotent stem cells analogous to naïve and primed embryonic stem cells of the mouse

Bhanu Prakash V.L. Telugu, Toshihiko Ezashi and R. Michael Roberts

Int. J. Dev. Biol. (2010) 54: 1703-1711

http://dx.doi.org/10.1387/ijdb.103200bt

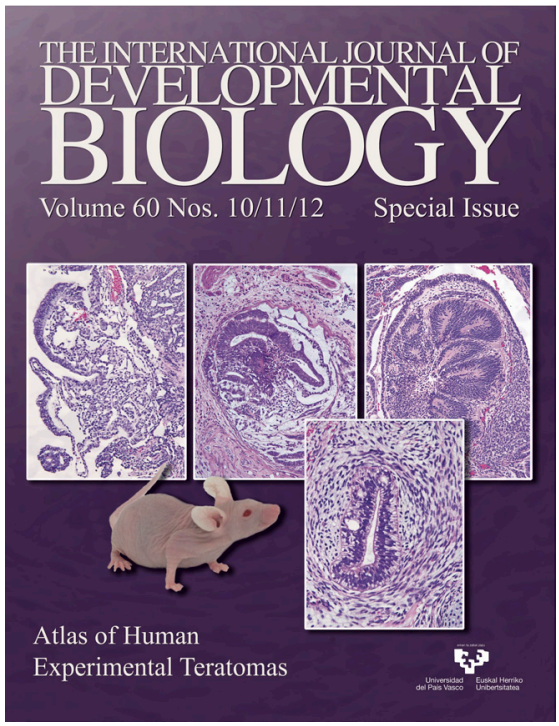

5 yr ISI Impact Factor $(2013)=2.879$
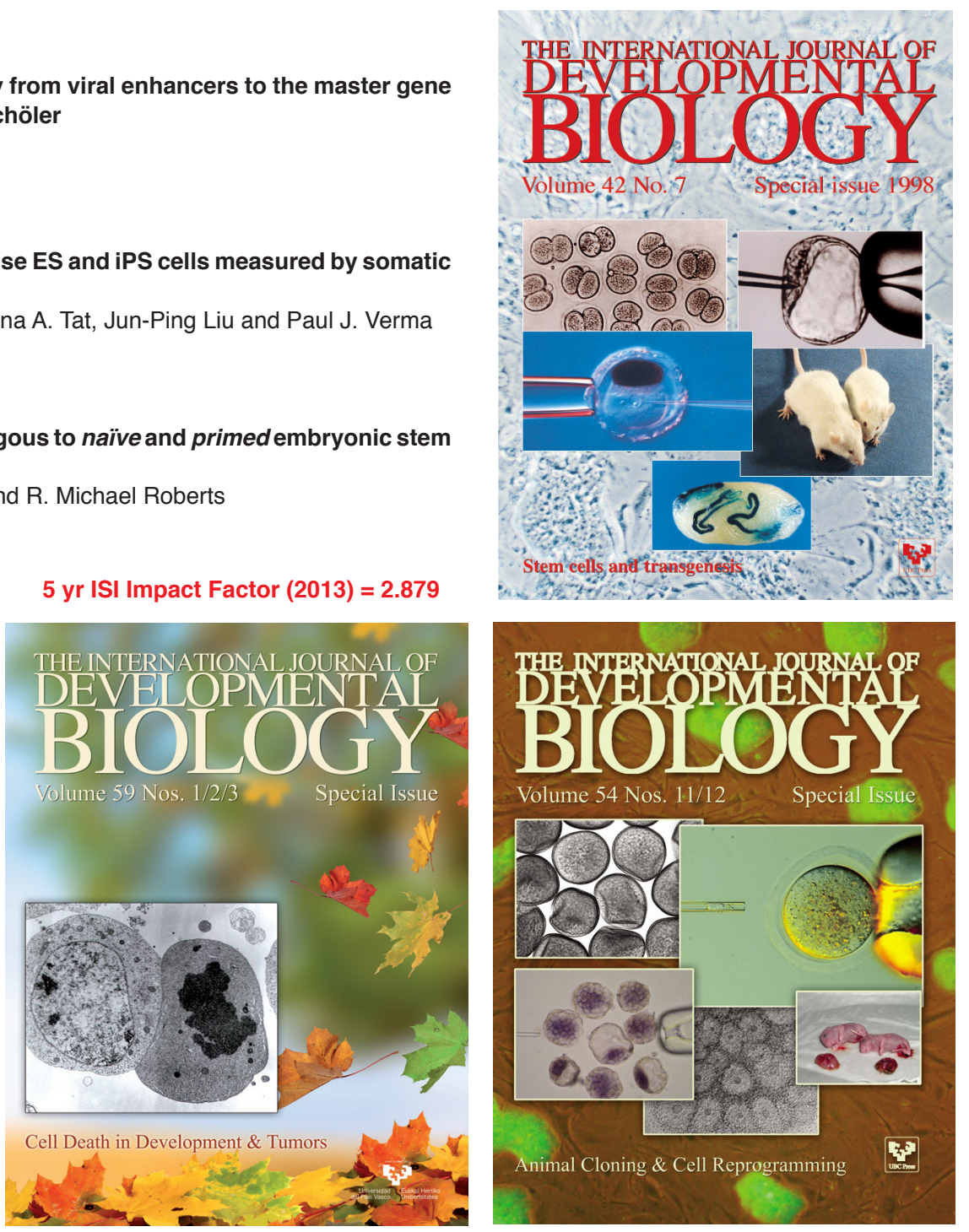